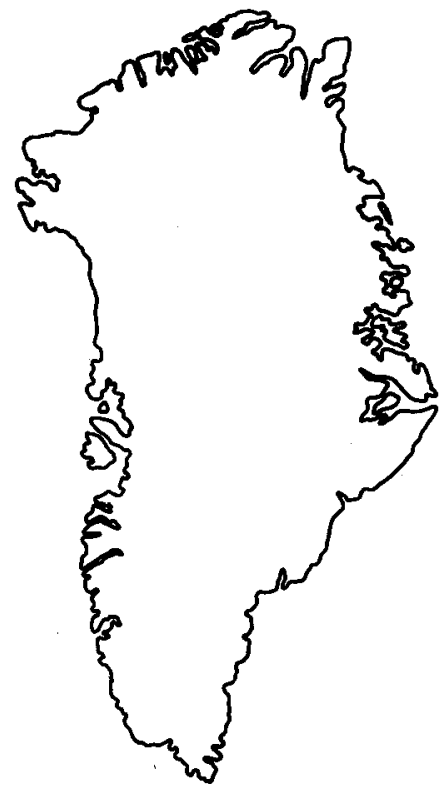

\title{
New names for Ordovician formations in Greenland
}

\author{
John S. Peel and John W. Cowie
}

\begin{abstract}
The names Cass Fjord Formation and Cape Weber Formation are restricted to strata in the vicinity of the type area of western North Greenland (and adjacent Ellesmere Island) and East Greenland, respectively. The so-called Cass Fjord Formation of East Greenland is renamed the Antiklinalbugt Formation, while the Cape Weber Formation of Washington Land, eastern North Greenland, is renamed the Canyon Elv Formation.
\end{abstract}

J.S.P. Grønlands Geologiske Undersøgelse, Øster Voldgade 10, DK-1350 København K, Danmark.

J.W.C. Department of Geology, University of Bristol, Queen's Building, University Walk, Bristol BS8 1TR, U.K.

The Cambro-Ordovician rocks of Greenland are best known in Inglefield Land, North-West Greenland, in Washington Land, eastern North Greenland, and in East Greenland (fig. 1), although extensive outcrops also occur elsewhere in North Greenland and in North-East Greenland (Dawes, 1976; Dawes \& Peel, in press; Henriksen \& Higgins, 1976). The foundation for this present state of knowledge lies in a series of expeditions to Greenland led by Lauge Koch which spanned almost half of the present century (summaries in Koch, 1940; Koch, 1954).

Collections of Cambrian - Early Ordovician (Canadian) fossils from northern Greenland brought back by the earlier expeditions were determined by Christian Poulsen (1927) who named stratigraphic units subsequently described by Koch (1929a; 1929b; 1933). Strata of similar age in East Greenland were described by Poulsen $(1930 ; 1937)$ as a participant in the Danish Expedition to East Greenland of 1929 under the leadership of Koch, and he later returned to the sequence on Ella $\varnothing$ (Poulsen \& Wienberg Rasmussen, 1951).

In view of the close association of Christian Poulsen with the establishment of Cambro-Ordovician stratigraphic nomenclature in East Greenland and northern Greenland (together with adjacent Ellesmere Island, see Poulsen, 1946) it is not surprising to find that two formation names - Cass Fjord Formation and Cape Weber Formation - have been employed in both areas of Greenland. However, due to the great distance $(c .1000 \mathrm{~km})$ separating the two areas of outcrop (fig. 1) and differences in the respective geological sections in terms of both sequence and age of strata (fig. 2), the common use of the two formation names is here discontinued. Thus, both formations are only recognised in the general area in which they were originally described. Strata in North-West, and western North Greenland assigned by Poulsen (1946) and Troelsen (1950) to the Cape Weber Formation are renamed the Canyon Elv Formation, while the former 


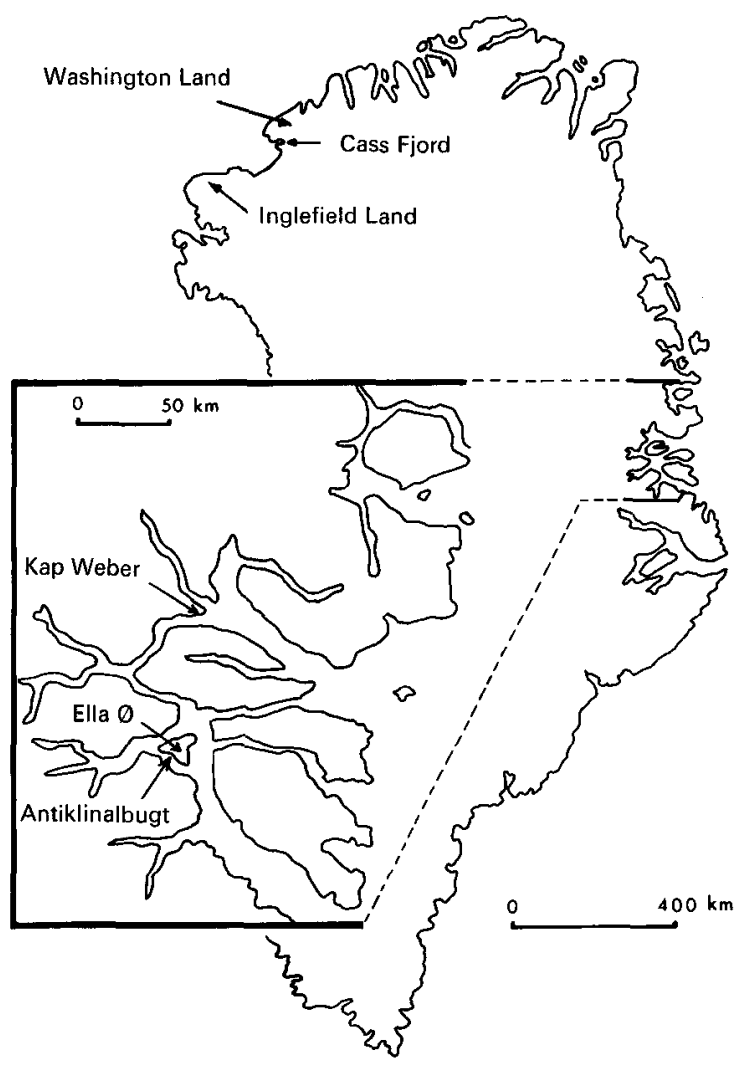

Fig. 1. Cambro-Ordovician localities in western North Greenland and East Greenland.

Cass Fjord Formation of East Greenland (Poulsen, 1930; Cowie \& Adams, 1957) is renamed the Antiklinalbugt Formation.

\section{Previous usage}

\section{Cass Fjord Formation}

This name was apparently first employed by Poulsen (1927) for a sequence in southern Washington Land, although brief lithological descriptions of the strata in question were given by Koch $(1923 ; 1924 ; 1925)$. Koch (1929a) gave a full description under the name Cass Fjord Formation during his geological account of the south coast of Washington Land. He later gave the type locality as the coast north-west of Kap Clay (fig. 4) and the date of authorship as 1922 (Koch, 1929b, p. 25), although this date apparently relates to his field observations and not to the date of publication. The formation was named after Cass Fjord, Washington Land. A preliminary redescription was given by Henriksen \& Peel (1976).

Koch (1929b) also tentatively referred intraformational conglomerates supposedly forming low plains between Kap Harald Moltke and Falkefjeld (= Mt. Falcon) in Peary Land, eastern North Greenland to the Cass Fjord Formation, but Peel \& Christie (1975) and Christie \& Peel (1977) have not recognised the formation in central southern Peary Land. Christie (1967) fol- 


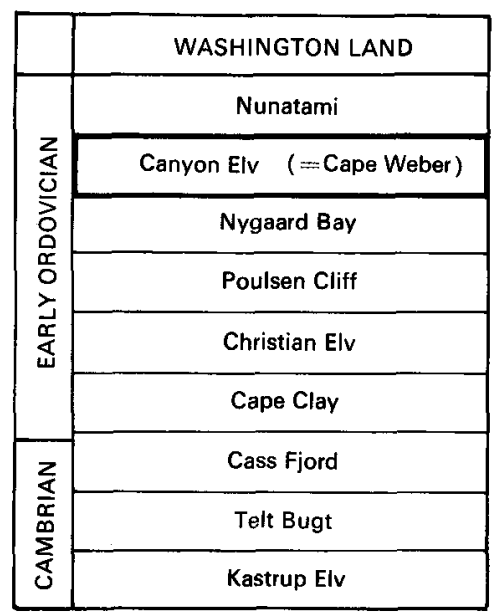

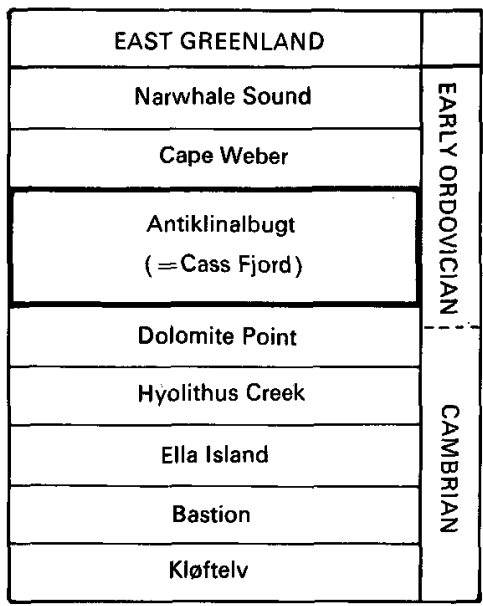

Fig. 2. Cambrian - Early Ordovician formations in Washington Land, western North Greenland, and in East Greenland. Replaced formation names are given in brackets. No correlation is implied between the two sections. Un-named Cambrian clastic sediments below the Kastrup Elv Formation in Washington Land are omitted.

lowed Troelsen (1950) in recognising a Cass Fjord Formation on Bache Peninsula, Ellesmere Island, some $200 \mathrm{~km}$ south-west of the type locality in Washington Land.

The term Cass Fjord Formation was introduced into East Greenland geology by Poulsen (1930), who mentioned that good sections occurred at Kap Weber and on Ella $\varnothing$ (fig. 1) - the latter subsequently revisited (Poulsen \& Wienberg Rasmussen, 1951). Poulsen (1930) commented that the strata agreed both lithologically and palaeontologically with the Cass Fjord Formation in its type area in western North Greenland. The fauna, dominated by the trilobites Hystricurus and Symphysurina, was described by Poulsen (1937).

Cowie \& Adams (1957) followed Poulsen in employing the Cass Fjord Formation for strata between the Dolomite Point and Cape Weber Formations in East Greenland (fig. 2). Sections on Ella $\varnothing$ and in Albert Heim Bjerge, c. $200 \mathrm{~km}$ to the north, were fully described and Poulsen's faunal list expanded. Subsequent workers (e.g. Haller, 1971; Henriksen \& Higgins, 1976) have largely followed Cowie \& Adams (1957).

\section{Restricted usage}

The name Cass Fjord Formation is here restricted to strata occurring in Washington Land, and probably also in Inglefield Land (fig. 1), (Koch 1929a, 1933; Troelsen, 1950) and the Bache Peninsula region of Ellesmere Island (Christie, 1967). In the type area around Cass Fjord, the formation conformably overlies the Telt Bugt Formation and is itself overlain by the Cape Clay Formation (Henriksen \& Peel, 1976; figs 2, 4). The formation has yielded a fauna dominated by trilobites of late Middle Cambrian, Late Cambrian and Early Ordovician age in Washington Land.

The erstwhile Cass Fjord Formation of East Greenland is renamed Antiklinalbugt Formation, defined below. 


\section{Antiklinalbugt Formation}

\section{Derivation of name}

new name

After Antiklinalbugt, on the southern side of Ella $\varnothing$ (fig. 1), along the shore of Narvhalsund. The name replaces the term Cass Fjord Formation as used by Poulsen $(1930 ; 1937)$. Poulsen \& Wienberg Rasmussen (1951) and Cowie \& Adams (1957) in East Greenland.

\section{Type locality}

In the cliffs of Antiklinalbugt, Ella $\varnothing$, on the eastern limb of the anticline (fig. 3).

\section{Description}

A description of the formation and definitions of its boundaries and subdivisions are given in Cowie \& Adams (1957, pp. 31-34, 98-103, 183-185, plates $X$ and XII). Cowie \& Adams (1957) considered the formation to be of Early Canadian (early Early Ordovician) age.

\section{Previous usage}

\section{Cape Weber Formation}

Koch (1929c) applied the name Cape Weber Formation to a series of fossiliferous Ordovician rocks at Kap Weber, Andree Land, East Greenland (fig. 1), although the date of authorship is

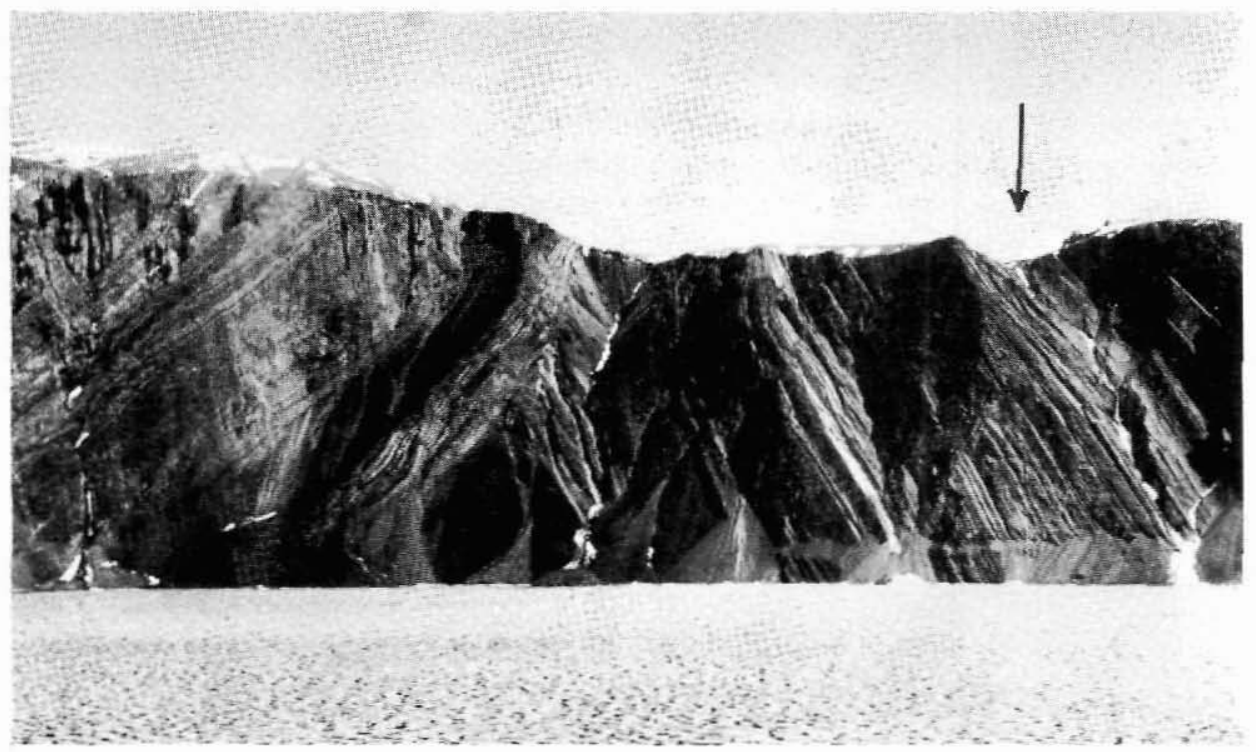

Fig. 3. Antiklinalbugt. Ella Ø. East Greenland, looking north. The pale weathering, steeply dipping Antiklinalbugt Formation on the east side of the anticline is arrowed. 
claimed to be 1927 by Koch (1929b, p. 30). Poulsen (1930) extended the formation to include higher beds of the underlying Eskimo Hut Formation of Koch (1929b), lower beds of the latter formation being referred by Poulsen to the Cass Fjord Formation (Antiklinalbugt Formation herein). Outcrops of the Cape Weber Formation in Ella $\varnothing$ were subsequently redescribed by Poulsen \& Wienberg Rasmussen (1951).

Cowie \& Adams (1957) summarised earlier contributions to the study of the Cambro-Ordovician in East Greenland and presented detailed sections and descriptions of the Cape Weber Formation (referred to as the Kap Weber Formation) in Albert Heim Bjerge and Ella $\varnothing$. They commented that the lower junction of the formation with the underlying Cass Fjord Formation (= Antiklinalbugt Formation) at Kap Weber, interpreted by Poulsen (1930) as an erosion surface, was of tectonic origin.

The name Cape Weber Limestone was given by Troelsen (1950, p. 51) to a "hard, gray or brownish, thick-bedded limestone with nodules and lenses of white chalklike calcite and dolomite" occurring between the Nygaard Bay Limestone and Nunatami Formation on the northern side of Cass Fjord in southern Washington Land. Troelsen (1950) considered that Koch (1929a) had generally included the limestone within the older Cape Clay Formation due to a mistaken correlation across Cass Fjord. Poulsen (1946) had previously assigned strata in Ellesmere Island to the Cape Weber Formation and speculated that the unit probably occurred in Washington Land above the Nunatami Formation. As noted by Troelsen (1950), the limestone in question occurs below the Nunatami Formation in Washington Land (fig. 2).

\section{Restricted usage}

The term Cape Weber Formation is restricted to strata described under that name by Poulsen (1930) and Cowie \& Adams (1957) in East Greenland. The formation (thickness c. $1100 \mathrm{~m}$ )

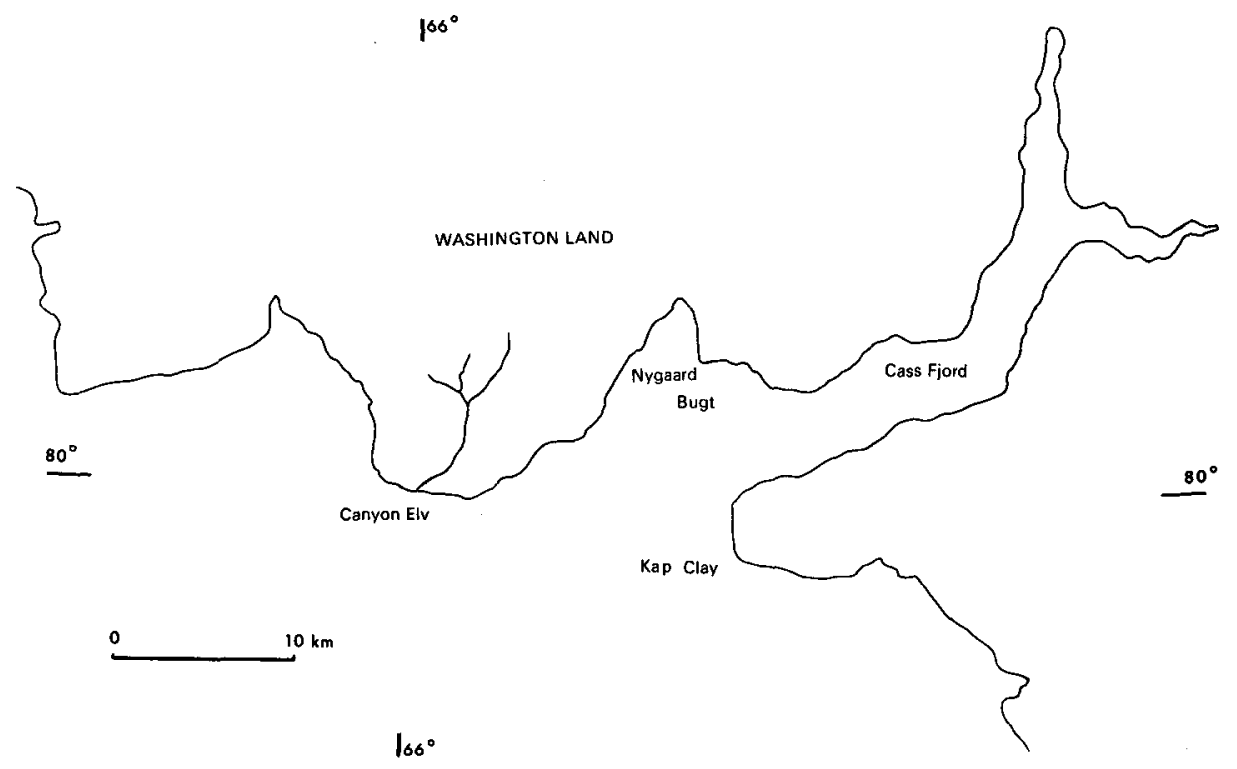

Fig. 4. Southern coast of Washington Land. 
overlies the Antiklinalbugt Formation (former Cass Fjord Formation) of Early Canadian age and is itself overlain by the Narwhale Sound Formation of Late Canadian age (fig. 2). The socalled Cape Weber Limestone of Washington Land, western North Greenland, referred to as the Cape Weber Formation by Troelsen (1956), is renamed the Canyon Elv Formation, described below.

\section{Canyon Elv Formation}

new name

\section{Derivation of name}

From Canyon Elv, a deeply incised river flowing into Kane Basin on the southern coast of Washington Land between Kap Webster and Gonioceras Bugt (fig. 4, 5). Canyon Elv Formation, a name employed in the field by J.C. Troelsen, replaces the term Cape Weber Formation of Troelsen (1950; 1956).

\section{Type locality}

At the mouth of Canyon Elv (fig. 5). In the cliff section, illustrated by Troelsen (1950, fig. 7), the Canyon Elv Formation at the cliff foot is overlain by the Nunatami Formation. The boundary with the underlying Nygaard Bay Formation is not exposed at the type locality, but is present in cliff exposures to the east.

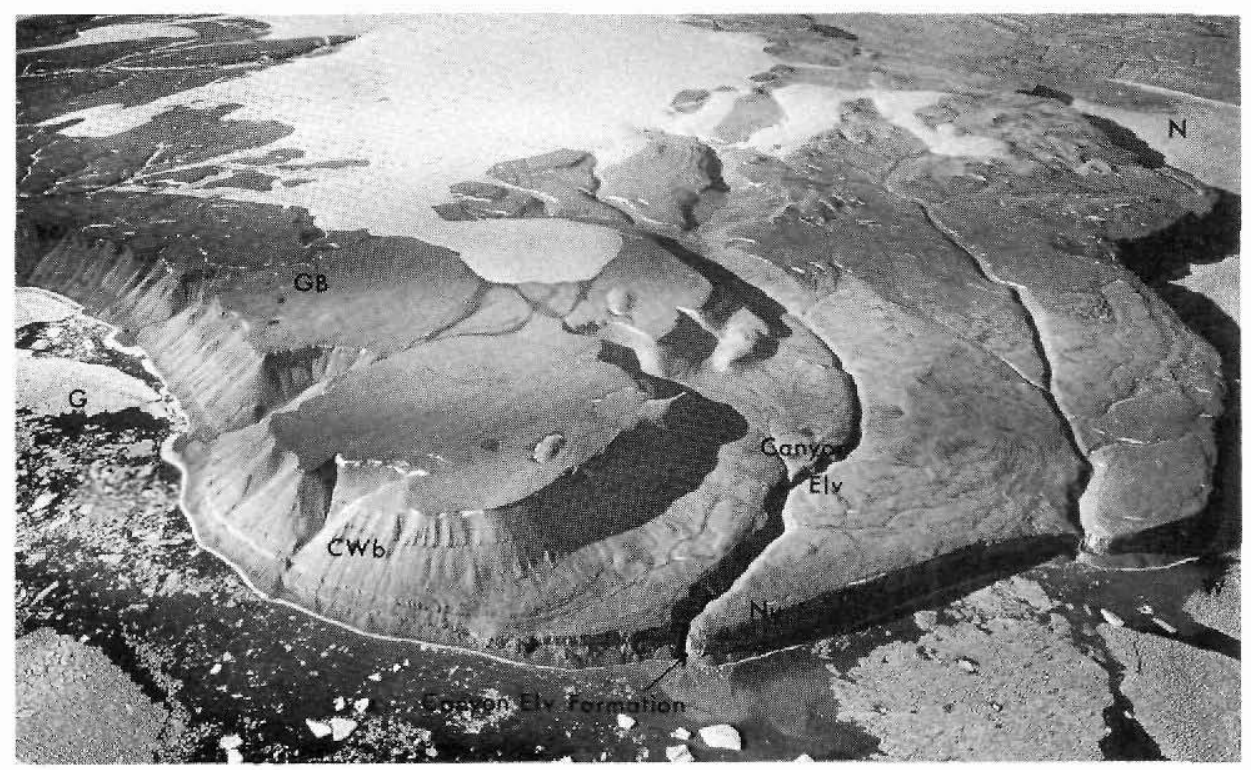

Fig. 5. Canyon Elv, looking toward the north-east. The type locality of the Canyon Elv Formation is at the foot of the cliffs by the mouth of the stream. G, Goniocras Bugt; N, Nygaard Bugt: W, Kap Webster. $\mathrm{CWb}$, Cape Webster Formation; GB, Gonioceras Bay Formation; Nu, Nunatami Formation, forming most of the sea cliffs (photograph: copyright Geodætisk Institut, Denmark (A.495/79)). 


\section{Description}

The nodules and thin bands of white dolomite reported by Troelsen (1950) characterise most of the Canyon Elv Formation. The enclosing limestone is hard, purplish-grey, weathering to yellow-grey, although in the cliffs between Kap Webster and Nygaard Bugt the outcrop may seem to be reddish-brown in comparison with the overlying, grey weathering Nunatami Formation. The limestone is generally fine grained, although scattered patches of intraformational conglomerate contain clasts up to $1 \mathrm{~cm}$. Bedding is crude, $10-50 \mathrm{~cm}$ beds, although a fine subparallel lamination is characteristic of some of the more strongly dolomite-banded intervals. Troelsen (1950) estimated the thickness of the formation to be about $10 \mathrm{~m}$ but recent fieldwork (Peel, 1977) demonstrated that the formation approaches $50 \mathrm{~m}$ in thickness.

The boundary with the overlying, thin bedded, fine grey limestones of the Nunatami Formation is seemingly gradational over a few centimeters, although the distinctive white patches and bands are confined to the Canyon Elv Formation. Brownish limestone and intraformational conglomerate, with thin interbedded shale, of the Canyon Elv Formation appear to conformably overlie anhydritic shale with thin intraformational conglomerate beds of the upper part of the Nygaard Bay Formation.

The Canyon Elv Formation is considered to be of Late Canadian age (late Early Ordovician) on the basis of trilobites identified by Poulsen in Troelsen (1950).

Acknowledgements. A.K. Higgins, P.R. Dawes and N. Henriksen kindly criticised the manuscript.

\section{References}

Christie, R.L. 1967: Bache Peninsula, Ellesmere Island, Arctic Archipelago. Mem. geol. Surv. Can. 347, 63 pp.

Christie, R.L. \& Peel, J.S. 1977: Cambrian-Silurian stratigraphy of Børglum Elv, Peary Land, eastern North Greenland. Rapp. Grønlands geol. Unders. 82, $48 \mathrm{pp}$.

Cowie, J.W. \& Adams, P.J. 1957: The geology of the Cambro-Ordovician rocks of central East Greenland. 1. Meddr Gronland 153(1), 193 pp.

Dawes, P.R. 1976: Precambrian to Tertiary of northern Greenland. In Escher, A. \& Watt, W.S. (edit.) Geology of Greenland, 248-303. Copenhagen; Geol. Surv. Greenland.

Dawes, P.R. \& Peel, J.S. in press: The northern margin of Greenland from Baffin Bay to the Greenland Sea. In Nairn, A.E.M., Stehli, F.G. \& Churkin, M. (edit.) The Ocean Basins and Margins 5, The Arctic Ocean. New York; Plenum.

Haller, J. 1971: Geology of the East Greenland Caledonides, 413 pp. London: Interscience.

Henriksen, N. \& Higgins, A.K. 1976: East Greenland Caledonian fold belt. In Escher, A. \& Watt, W.S. (edit.) Geology of Greenland, 182-247. Copenhagen: Geol. Surv. Greenland.

Henriksen, N. \& Peel, J.S. 1976: Cambrian - Early Ordovician stratigraphy in south-western Washington Land. Rapp. Grønlands geol. Unders. 80, 17-23.

Koch, L. 1923: Resultaterne af Jubilæumsekspeditionen Nord om Grønland i 1921. Naturens Verden 1923, 49-76.

Koch, L. 1924: De videnskabelige resultater af Jubilæumsekspeditionen Nord om Grønland. Rapport I: Kartografi og geologi. Geografisk Tidsskrift 27, 208-218.

Koch, L. 1925: The geology of North Greenland. Amer. J. Sci. (5) 9, 271-285.

Koch, L. 1929a: The geology of the south coast of Washington Land. Meddr Grønland 73(1), 1, $39 \mathrm{pp}$.

Koch, L. 1929b: Stratigraphy of Greenland. Meddr Grenland 73(2), 2, 205-320. 
Koch, L. 1929c: The geology of East Greenland. Meddr Gronland 73(2), 1, $204 \mathrm{pp}$.

Koch, L. 1933: The geology of Inglefield Land. Meddr Grønland 73(1), 2, 38 pp.

Koch, L. 1940: Survey of North Greenland. Meddr Gronland 130,1, 364 pp + atlas.

Koch, L. 1954: Literature from the Danish East Greenland Expeditions published in the Meddelelser om Grønland. Meddr Grønland 143,3, 20 pp.

Peel, J.S. 1977: Cambrian-Silurian studies in Washington Land, western North Greenland. Rapp. Grenlands geol. Unders. 85, 30-33.

Peel, J.S. \& Christie, R.L. 1975: Lower Palaeozoic stratigraphy of southern Peary Land, eastern North Greenland. Rapp. Grønlands geol. Unders. 75, 21-25.

Poulsen, C. 1927: The Cambrian, Ozarkian and Canadian faunas of Northwest Greenland. Meddr Granland 70(1), 2, 233-343.

Poulsen, C. 1930: Contributions to the stratigraphy of the Cambro-Ordovician of East Greenland. Meddr Grønland 74, 297-316.

Poulsen, C. 1937: On the Lower Ordovician faunas of East Greenland. Meddr Grønland 119(3), $72 \mathrm{pp.}$

Poulsen, C. 1946: Notes on the Cambro-Ordovician fossils collected by the Oxford University Ellesmere Island Expedition 1934-35. Quart. Jl geol. Soc. London 102, 299-337.

Poulsen, C. \& Wienberg Rasmussen, H. 1951: Geological map (scale 1:50.000) and description of Ella Ø. Bull. Grønlands geol. Unders. 3 (also Meddr Grønland 151,5), 25 pp.

Troelsen, J.C. 1950: Contributions to the geology of Northwest Greenland, Ellesmere Island and Axel Heiberg Island. Meddr Grønland 149(7), 86 pp.

Troelsen, J.C. 1956: Lexique stratigraphique international. Vol. 1 Europe, fasc. 1 a, Groenland. Centre National de la Recherche Scientifique, Paris, $116 \mathrm{pp}$. 